\title{
Meteorological Parameters and Mosquito Species Diversity and Abundance along the Arabian Sea Coastline of Alappuzha District, India: A Year-round Study (2017-18)
}

Pratip Shil $^{1}$, R. Balasubramanian ${ }^{1,2} \not$

1 ICMR-National Institute of Virology, 130/1 Sus Road, Pashan, Pune 411021, India

2 ICMR-National Institute of Virology-Kerala Unit, Alappuzha-688005, Kerala, India

\Corresponding author email: balasniv@gmail.com

Journal of Mosquito Research, 2020, Vol.11, No.2 doi: 10.5376/jmr.2020.11.0002

Received: 24 Jul., 2020

Accepted: 23 Aug., 2020

Published: 28 Aug., 2020

Copyright (c) 2020 Shil and Balasubramanian, This is an open access article published under the terms of the Creative Commons Attribution License, which permits unrestricted use, distribution, and reproduction in any medium, provided the original work is properly cited.

Preferred citation for this article:

Shil P., and Balasubramanian R., 2020, Meteorological parameters and mosquito species diversity and abundance along the Arabian sea coastline ofAlappuzha district, India: A year-round study (2017-18), Journal of Mosquito Research, 11(2): 1-11 (doi: $\underline{10.5376 / j m r .2020 .11 .0002)}$

\begin{abstract}
Tropical countries like India has a huge burden of vector-borne diseases, necessitating studies on mosquito demographics for effective control. In the present paper, we summarize the findings of a 12-month entomological survey conducted to determine the diversity of mosquitoes in human settlements located along the Arabian Sea shoreline in Alappuzha district, Kerala, India. Adult mosquitoes were sampled using modified CDC light-traps operated in dusk to dawn operations at ten trapping sites. Captured mosquitoes were transported to laboratory and identified using standard entomological keys. Shannon's diversity and evenness were calculated to evaluate the richness and diversity of mosquito species. A total of 20 species were identified across five genera. Culex tritaeniorhynchus is the eudominant species followed by Culex quinquefasciatus and Culex gelidus. The seasonal variability of $C x$. tritaeniorhynchus and Cx. gelidus, the two principal vectors for West Nile and Japanese Encephalitis viruses, were studied. The present study provided valuable information about the mosquito demographics and seasonal variability of abundance in human settlements along the Arabian Sea shoreline in Alappuzha, India. Considering the venerability of the area to vector-borne diseases due to ecology and presence of migratory birds, future studies may be necessitated to determine the association between vector biodiversity and risk of viral disease transmission to humans.
\end{abstract}

Keywords India; Mosquito; Species diversity; Abundance; Meteorological parameters; Coastline

\section{Background}

Over the last decade there had been a dramatic increase in the spread of vector-borne viral diseases (VBD) worldwide (Shope, 1991; Sudeep et al., 2008; Angle et al., 2008; Manimunda et al., 2010; Gubler, 2010; Sudeep et al., 2011; Dash et al., 2013; Kumawat et al., 2014; Bueno-Mari et al., 2015). Apart from distribution and abundance of vectors, vector-host interactions and complicated vector-pathogen-host interactions, the spread of VBDs has also been found to depend on various climatic factors (Epstein, 1998; Rieter, 2001; Gould et al., 2009; Lafferty, 2009; Dash et al., 2013; Roiz et al., 2014). It has been established that climate change is affecting propagation mosquitoes which in turn has driven the spread of mosquito borne diseases (Monaghan et al., 2018). Resurgence of Dengue, Chikungunya and most recently of Zika resulted in considerable human sufferings and economic burden (Dash et al., 2013; Mourya et al., 2016) in developing countries like India. High mosquito abundance has proved to be a prelude to VBD epidemics (Shil et al., 2018 b; Lafferty, 2009). Meteorological factors like rainfall, relative humidity and temperature (including diurnal temperature range, DTR) play important role in the survival and propagation of mosquitoes as well as vector competence to disease like Dengue, Chikungunya, Malaria, Zika, Japanese encephalitis, West Nile, etc. (Dash et al., 2013; Shil et al., 2018a). This necessitates research to understand the role of climate factors in the spread of mosquito borne diseases.

India has a huge burden of Dengue and Chikungunya (Shil et al., 2018b) with more than 6 million affected between 2010 and 2017 (National Vector Borne Disease Control Programme, Government of India). Apart from these, a sporadic outbreak of West Nile has been reported from southern state of Kerala (Balakrishnan et al., 2016). Recent serological survey in the Alappuzha district, Kerala has revealed $21.5 \%$ and $15.9 \%$ of those surveyed to be positive for West Nile virus and Japanese encephalitis virus respectively (Balakrishnan et al., 2017). 
The Kerala state of India has unique geophysical features like the backwaters along the Arabian Sea coast at places, sandy beaches in some others. While the climate is hot and humid, heavy rainfall occurs under the effects of South West (SW) Monsoon as well as North East (NE) monsoon. The hot and humid tropical climate with high green cover presents ideal settings for mosquito habitats (Balasubramanian and Nikhil, 2015). Abundance of mosquitoes, tourism and rich diversity of local water-birds and their interactions with migratory birds make Kerala a potential breeding ground for zoonotic viral diseases. Coastal Kerala remained a good feeding and nursery ground for a variety of heron, egrets and migratory birds, which are amplifying hosts for Japanese encephalitis and West Nile virus. Recently, Kalaiyarasu et al. (2016) has reported serological evidence of widespread Japanese Encephalitis and West Nile virus infections in native domestic ducks in Kerala. However, there are no comprehensive reports on the role of environmental factors and seasonal variability of vector (mosquito) population, which can propagate these diseases to humans. These necessitate research to understand the role of meteorological factors on abundance and diversity of mosquito demographics in the Alappuzha region of Kerala.

In this paper we are presenting the results of a year-round study on the mosquito population in the coastal villages along the Arabian Sea shoreline of Alappuzha district Kerala, India. We also made an attempt to understand the influence of meteorological parameters on mosquito population and seasonal variability. The purpose of the study was to investigate the seasonal variability in abundance of mosquitoes with stress on Culex species, the potential vectors for JE and WN viruses.

\section{Materials and Methods}

\subsection{Survey area and climate}

Alappuzha is a district of Kerala state, India with the Arabian Sea on the west, a vast network of backwaters, lagoons and fresh water rivers crisscrossing the land. The total geographical area of district is $38,863 \mathrm{~km}^{2}$ and population of 21, 27,789 (Census of India, 2011). The district lies between 90 5' to 90 55' North latitude and 76 $017^{\prime}$ to 76046 ' East longitude. The district has $82 \mathrm{~km}$ stretch of sea shore. Land-use maps indicate large areas of the district being occupied by wetlands or by rice cultivation.

As per the Koppen classification, Kerala experiences Tropical wet type of climate due to its location at the southern tip of the Indian peninsula. While it is warm and humid year round, bulk of the rainfall occurs from June to October under the influence of South West Monsoon and sporadic rainfall from November-January under the influence of North East Monsoon (Koppen; Weather Atlas of India-IMD). In some years early onset of SW monsoon brings pre-monsoon showers in the month of May.

This district was known to be an area endemic for Japanese encephalitis and West Nile virus. The ecology provided a good feeding and nursery ground for a variety of egrets, heron, and migratory birds which are potential. These birds are amplifying host for Japanese encephalitis and West Nile virus.

\subsection{Adult mosquito collection and sampling}

Mosquitoes were trapped fortnightly from each location using modified CDC light trap, setup in the premises of houses with consent of the house-owner. A total of 10 fixed trapping locations were considered for the study. The traps were operated from dusk (one hour before sunset) to dawn (two hours after sun rise). All traps were suspended at a height of $1 \sim 2 \mathrm{~m}$ from the ground in the trees in the premises of houses. Collected mosquitoes were transported the laboratory in ice and identified using standard taxonomical keys (Shil et al., 2018a). All the trapping locations were $10 \sim 400 \mathrm{~m}$ from the shoreline.

\subsection{Meteorological data}

Meteorological parameters like monthly average maximum and minimum temperature, rainfall and relative humidity for the coastal villages were obtained from the Rice Research Station (RRS), Kerala Agricultural University-Alappuzha, Kerala. 


\subsection{Virus detection}

The method described by Sudeep et al. (2011), was followed for virus detection and isolation. Only $C x$. tritaeniorhynchus and Cx. gelidus mosquitoes were considered for virus detection.

\subsection{Mathematical \& statistical analyses:}

Mathematical and statistical data analyses were performed in MS Excel and R software.

For better estimation of the mosquito species richness diversity and evenness we have calculated the diversity indices as follows:

a) Shannon-Wiener's Diversity index:

Shannon-Weiner's diversity index is based on the uncertainty that an individual taken at random from the dataset is predicted correctly as a certain species. Larger values represent larger uncertainty and greater diversity of species.

Eqn (1) $\mathrm{H}^{\prime}=-\sum_{i=1}^{N} p_{i} \ln \left(p_{i}\right)$

Where $p_{i}=\mathrm{ni} / \mathrm{N} ; p_{i}=$ proportion of total sample represented by $i^{\text {th }}$ species and $n_{i}$ is the number of samples of the $i^{\text {th }}$ species.

The Shannon Wiener evenness is defined as:

Eqn (2) $E=\frac{H^{\prime}}{\ln (S)}$

Where $\mathrm{S}$ is the total number of species in any geographical location (e.g. total number of mosquito species), $\mathrm{H}^{\prime}$ is the Shannon-Wiener's Diversity index. Value lies between 0 and 1 . The value $E=1$ indicate complete evenness which signifies that all the species are equally abundant in the area/location. Evenness is a measure of the relative abundance of the different species making up the richness of an area.

b) Simpson's index of diversity:

Simpson's Index of Diversity (1-D), reflects the probability that two individuals taken at random from the dataset are not the same species (i.e., will belong to different species). It is defined as:

$$
1-\mathrm{D}=1-\frac{\sum n_{i}\left(n_{i}-1\right)}{N(N-1)}
$$

Where $n_{i}$ is the number of the $i^{t h}$ species and $\mathrm{N}$ is the total number of specimens in the studied location.

The Heydemann's classification was used to evaluate the dominance structure (Spellerberg and Fedor, 2013). This classification has five degrees of dominance: Eudominant species-those making up $>30 \%$ of all specimens caught, dominant $(10 \% \sim 30 \%)$, subdominant $(5 \% \sim 10 \%)$, rare $(1 \% \sim 5 \%)$ and subrare $(<1 \%)$.

\section{Results}

\subsection{Study area}

The Alappuzha district is shown in the maps displayed in Figure 1. The list of ten villages considered as trapping sites are enlisted in Table 1.

\subsection{Mosquito demographics}

A total of 6741 adult mosquito specimens were subjected to identification using standard entomological keys. A total of 20 species were identified belonging to five genera viz., Aedes, Anopheles, Armigeres, Culex and Mansonia. Among the genera, Culex was the most diverse (9 species) followed by Anopheles (4), Aedes (3), Mansonia (3) and Armigeres (1). 
Culex mosquitoes constituted $78.3 \%$ of the total catch followed by Mansonia with $15.7 \%$, Armigeres with 4.62\%, Aedes with $0.52 \%$ and Anopheles with $0.86 \%$. The top three most abundant species was found to be: Cx. tritaeniorhynchus (41.7\%), Cx. quinquefasciatus (19.7\%) and Cx. gelidus (11.2\%). As per the Heydemann's classification (Weigmann et al., 1973; Spelberg et al., 2013), Cx. tritaeniorhynchus is the eudominant species followed by $C x$. quinquefasciatus and Cx. gelidus as the dominant species. The subdominant species is Ma. annulifera. Rare species included: Ar. subalbatus, Cx. sitiens, Ma. indiana, and Ma. uniformis.

Overall, considering the 12-months data, the Shannon-Wiener's diversity index was found to be $\mathrm{H}^{\prime}=1.82$ and Shannon evenness, $E=0.69$. This signified that all the species are not equally abundant in the study area. The Simpson's index of diversity was found to be $(1-D)=0.761$, which signified that there existed a strong probability that any two samples selected at random will not be the same species. This meant that high diversity exists.

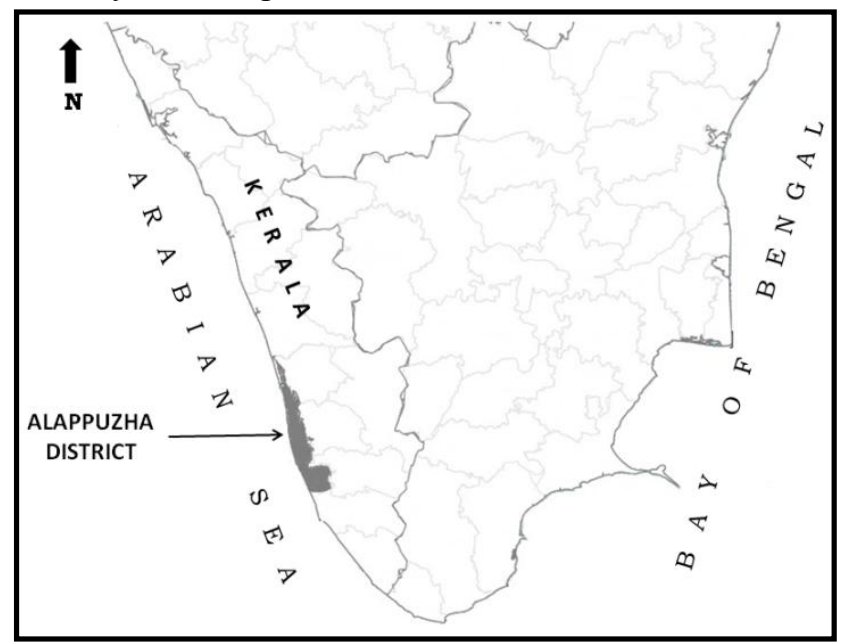

Figure 1Location of Alappuzha district in Kerala, India

Table 1 Sites for mosquito trapping in the coastal settlements in Alappuzha district

\begin{tabular}{ll}
\hline S1 No. & Name of Village/settlement \\
\hline 1 & Ambalapuzha \\
2 & Arthunkal \\
3 & Chethy \\
4 & Vandanam \\
5 & Alappuzha town \\
6 & Karoor \\
7 & Punnapra \\
8 & Thakazhy \\
9 & Thottappally \\
10 & Vadackal \\
\hline
\end{tabular}

\subsection{Meteorological factors and mosquito abundance}

\subsubsection{Total mosquito abundance}

Figure 2 shows the variation of mosquito abundance (MA) with maximum and minimum temperatures (MXT and MNT). While MXT varies over a range of $25.5^{\circ} \mathrm{C}$ to $30.9^{\circ} \mathrm{C}$ (annual average $\sim 27.8^{\circ} \mathrm{C}$, the MNT varies between $15.4^{\circ} \mathrm{C}$ to $19.5^{\circ} \mathrm{C}$ (annual average $18.3^{\circ} \mathrm{C}$ ). The temperature range is favorable for mosquito propagation and survival through-out the year. The Pearson's correlation coefficient for MA vs MXT was found to be: $\mathrm{r}=0.069$ ( $95 \%$ confidence, $p$-value $=0.0423)$ and that for $\mathrm{M}$ vs MNT was found to be $\mathrm{r}=-0.480(95 \%$ confidence, $\mathrm{p}$-value $=$ 0.689). This implies very weak association between temperature variations and mosquito abundance over the study period. 
Kerala receives most of the rainfall during the SW monsoon season covering June-July-August-September (JJAS) and some during the post monsoon season covering October-November-December (OND), while January-February-March (JFM) is mostly dry. In Figure 3 we compare the mosquito abundance with the monthly rain fall in the study area. A statistical analysis does not establish any proper correlation between total mosquito abundance (MA) and JJAS rainfall. On the other hand, the MA is negatively associated ( $\mathrm{r}=-0.96,95 \%$ confidence) with OND rainfall.

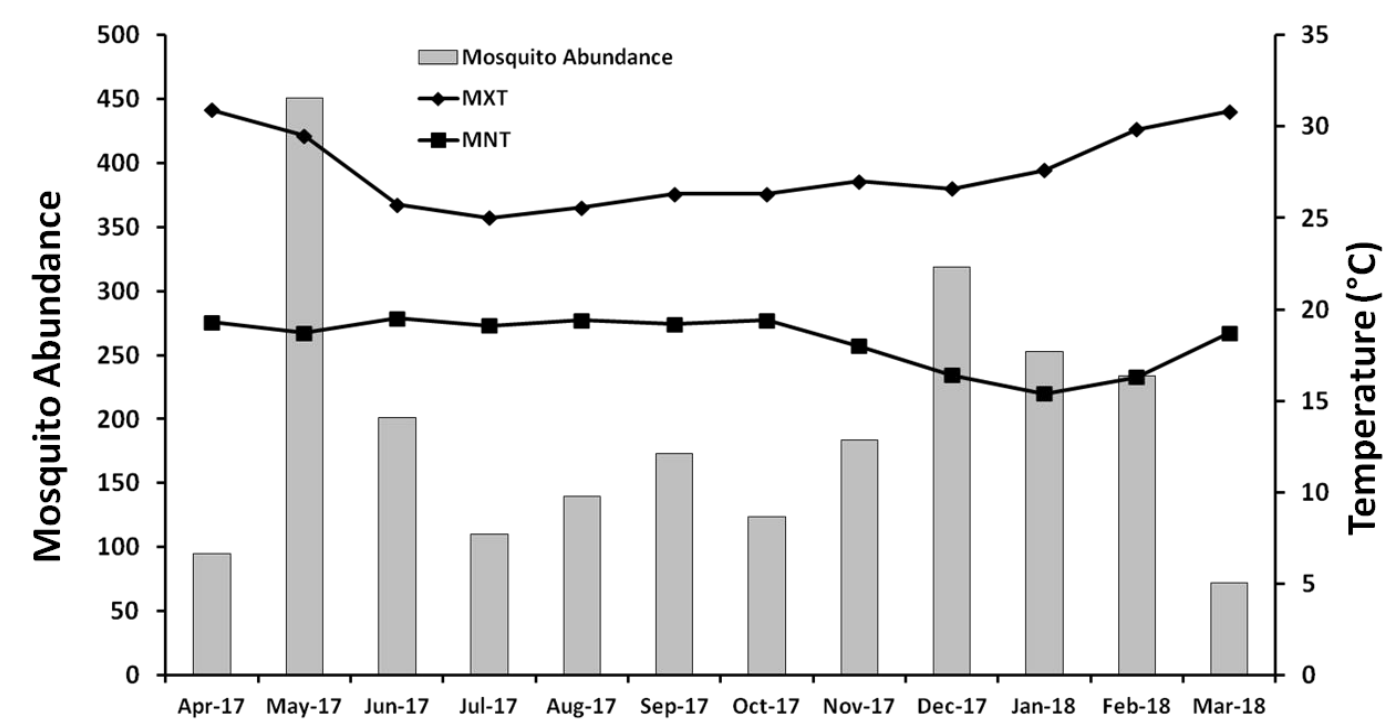

Figure 2 Mosquito abundance, Maximum and Minimum temperatures for the area surveyed

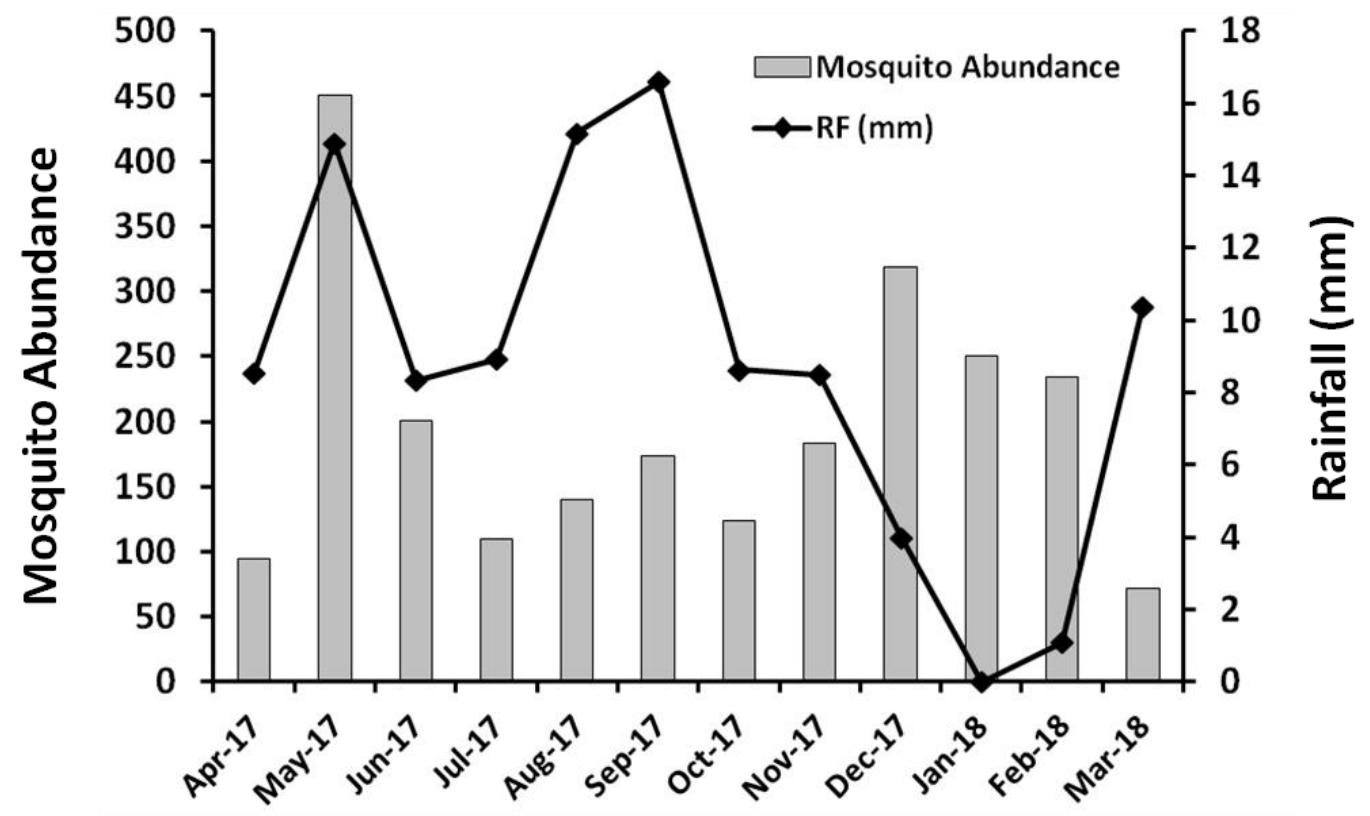

Figure 3 Mosquito abundance and rainfall for the area surveyed

\subsubsection{Culex mosquitoes}

Demographics indicated that the Culex mosquitoes were the dominant genera (78.4\%) in the study area. In addition, the Arabian Sea shoreline in Kerala has a high percentage of West Nile and Japanese encephalitis positivity in the local bird population 22. Hence, we have made separate detailed analyses for $C x$. tritaeniorhynchus and $C x$. gelidus the two main vectors for these viral diseases. 
Figure 4 shows the variation of $C x$. tritaeniorhynchus abundance with maximum and minimum temperatures (MXT and MNT). The temperature range is favorable for propagation and survival of $C x$. tritaeniorhynchus through-out the year. The Pearson's correlation coefficient for $C x$. tritaeniorhynchus abundance vs MXT was found to be: $\mathrm{r}=0.1862(95 \%$ confidence, $\mathrm{p}$-value $=0.562)$ and that for $C x$. tritaeniorynchus abundance vs MNT was found to be $\mathrm{r}=-0.296$ ( $95 \%$ confidence, $\mathrm{p}$-value $=0.350$ ). This implies that $C x$. tritaeniorhynchus mosquito abundance showed very weak positive association with maximum temperature and a weak negative association with minimum temperature during the study period.

Figure 5 compares the abundance of $C x$. tritaeniorhynchus and monthly rainfall. The Pearson's correlation coefficient, $\mathrm{r}=-0.483$ (95\% confidence, $\mathrm{p}$-value $=0.131)$ indicated a moderate negative association between $C x$. tritaeniorhynchus abundance and monthly rainfall.

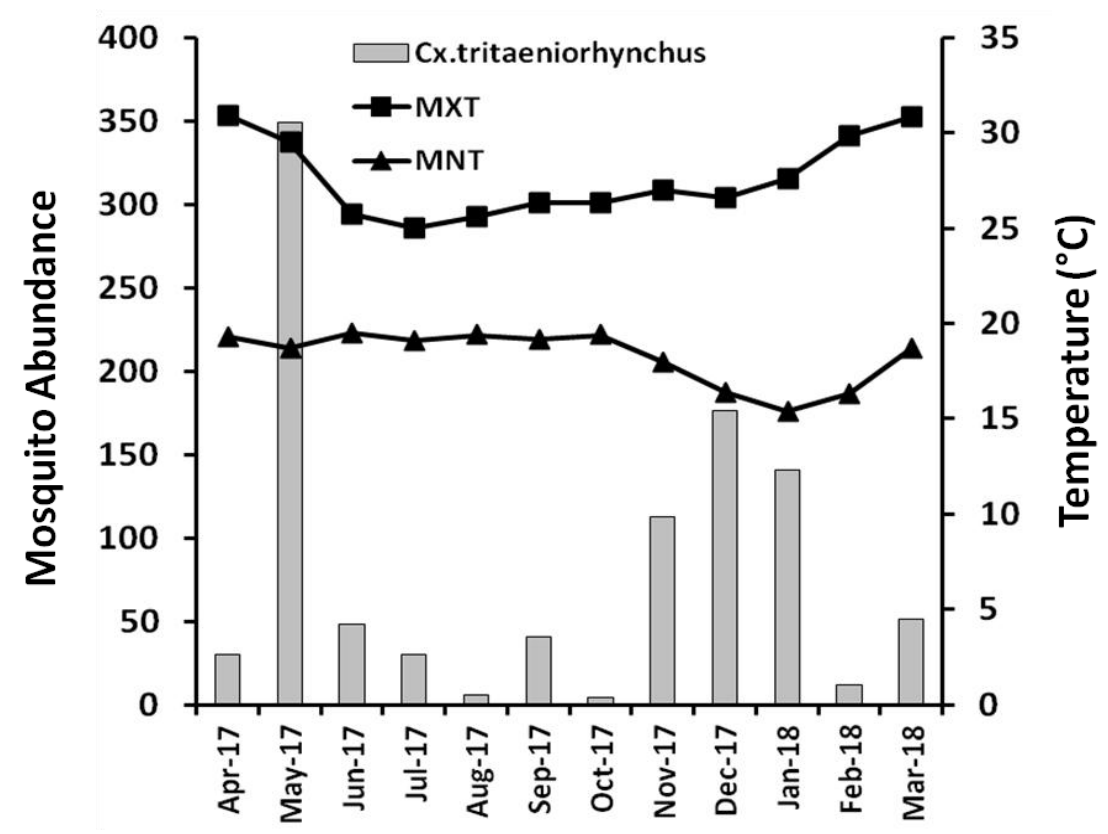

Figure 4 Variability in the abundance of Culex tritaeniorhynchus mosquitoes with temperature

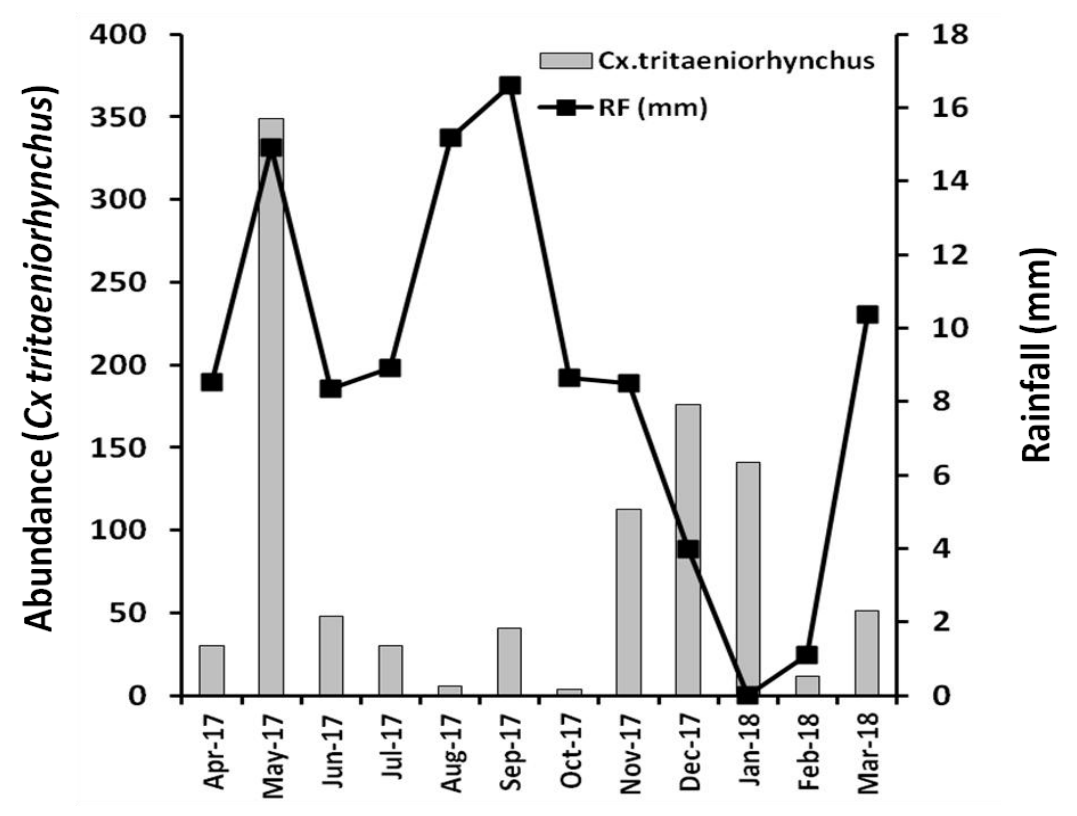

Figure 5 Variability in the abundance of Culex tritaeniorhynchus mosquitoes with rainfall 
Figure 6 shows the variation of $C x$. gelidus abundance with maximum and minimum temperatures (MXT and MNT). The temperature range is favorable for propagation and survival of $C x$. gelidus through-out the year. The Pearson's correlation coefficient for $C x$. gelidus abundance vs MXT was found to be: $\mathrm{r}=-0.236$ (95\% confidence, $\mathrm{p}$-value $=0.460)$ and that for $C x$. gelidus abundance vs MNT was found to be $\mathrm{r}=-0.294(95 \%$ confidence, p-value $=0.354)$. This implies that $C x$. gelidus abundance showed very weak positive association with maximum temperature and a weak negative association with minimum temperature during the study period.

Figure 7 indicates the abundance of $C x$. gelidus and monthly rainfall. The Pearson's correlation coefficient, $\mathrm{r}=-0.26(95 \%$ confidence, $\mathrm{p}$-value $=0.416)$ indicated a moderate negative association between $C x$. gelidus abundance and monthly rainfall.

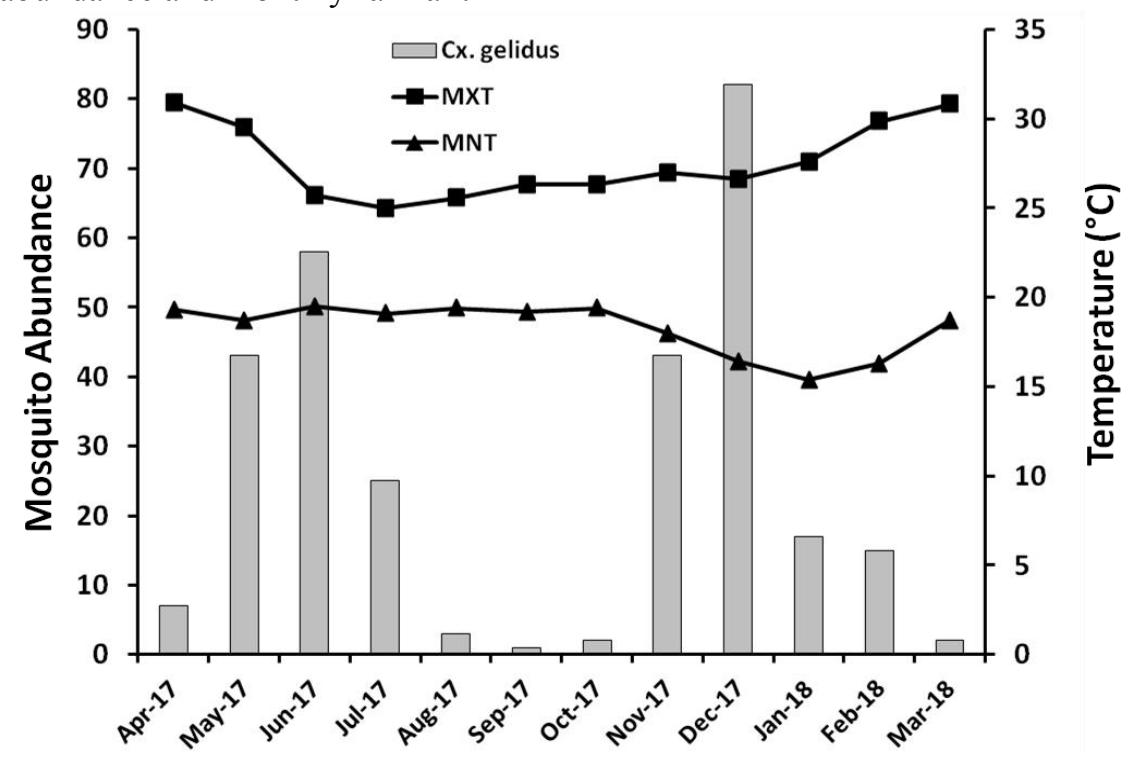

Figure 6 Variability in the abundance of Culex gelidus mosquitoes with temperature

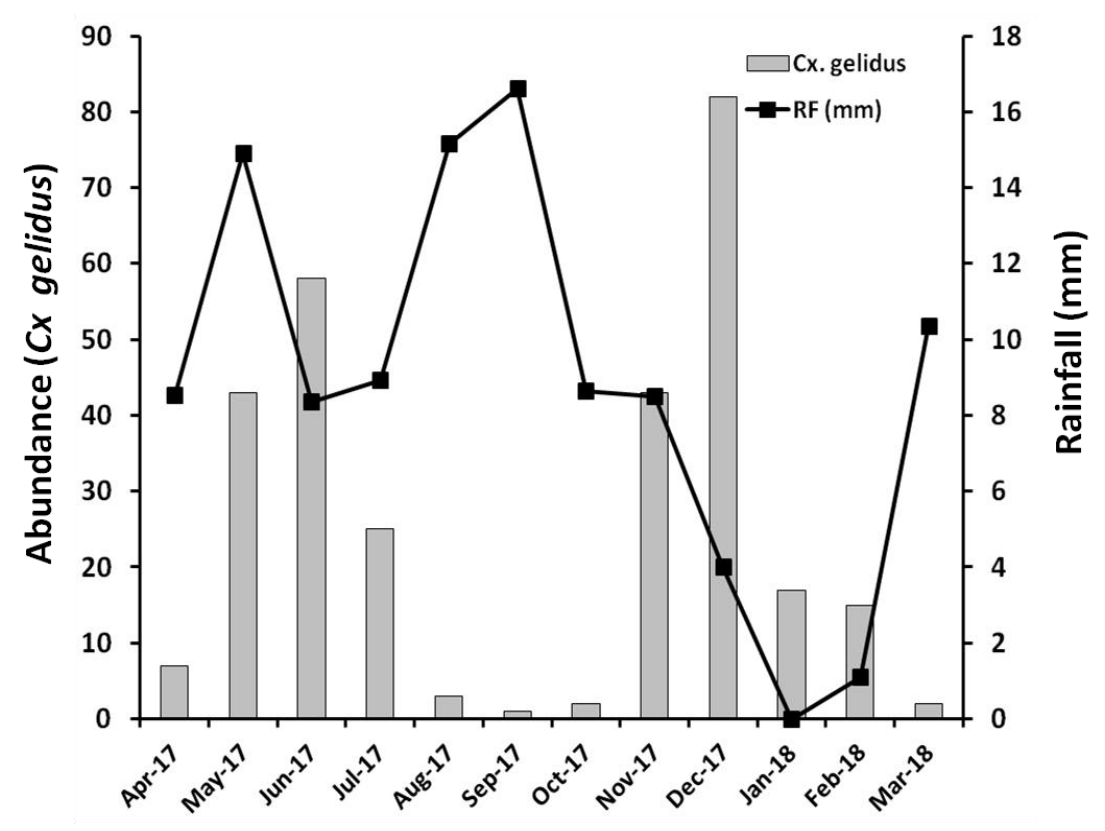

Figure 7 Variability in the abundance of Culex gelidus mosquitoes with rainfall 


\section{Discussions}

The purpose of the study was to conduct a survey of the mosquito population in the coastal human settlements along the Arabian Sea shoreline in the Alappuzha district, Kerala, India so as to understand the demographic diversity and seasonal variations. The aim was to detect the presence of Culex mosquitoes, the potential vectors for Japanese Encephalitis and West Nile viruses, these viruses having caused outbreaks in the Kerala state. Mosquito trapping was conducted in 10 fixed locations in the human settlements along the coastal villages between 10 400 $\mathrm{m}$ of the shoreline. All houses had gardens and trees planted in the premises, with abundance of fruit trees, with or without vegetable patches or flowerbeds. Small ponds, both temporary (Monsoon season) and permanent (year-round) were also located adjacent to some of the houses. Rice fields or cultivated lands were located around $400 \mathrm{~m}$ inland from the shoreline (sea beach). All the trapping sites had similar settings. Mosquito collections were performed fortnightly by light traps operated from dusk to dawn operations (one hour before sunset till one hour after sunrise). Mosquito abundance was calculated in terms of counts per trap.

Mosquito population showed a great deal of diversity in terms of species. A total of 20 species across five genera were detected. Simpson's index of diversity was used to measure the heterogeneity of the mosquito demographics in the study area. High value indicated the high level of diversity of mosquito species. The high value of Shannon-Weiner's diversity index indicated greater richness of the mosquito species. The Shannon-Weiner index of Evenness was found to be high at 0.69 , but it still indicated that all the species were not equally abundant in the area. This is similar to findings elsewhere in tropical and subtropical settings in Asia (Nikookar et al., 2015). While there were 9 species from the Culex genera, 4 from Anopheles, 3 each from Aedes and Mansonia, there was only one species from Armigeres. As per the Heydemann's classification criterion for dominance structure, $C x$. tritaeniorhynchus was eudominant, $C x$. quinquefasciatus and $C x$. gelidus were the dominant species. Ma. annulifera was subdominant. All the Aedes species were classified as sub-rare and so were the three Anopheles species.

Overall mosquito abundance showed seasonal variations. While highest abundance was observed in the month of May 2017, the least was observed in March 2018, which is the peak of the dry season. The influence of meteorological parameters on mosquito abundance was also evaluated in terms of time series analyses and Pearson's correlation coefficient was evaluated as a measure of association. In presence of favorable temperature, mosquito abundance was modulated by rainfall with the high rainfall months recording low abundance probably due to loss of habitat (washed out by flooding).

The study also revealed that Culex mosquitoes were most abundant in the area. Culex mosquitoes accounted for $78.4 \%$ of the total population. Cx. tritaeniorhynchus was the most abundant species probably because of humid tropical settings and abundant breeding habitat (closeness to paddy fields). The abundance of $C x$. tritaeniorhynchus was maximum in the pre-monsoon season. During SW monsoon (JJAS), the rainfall was steady and moderate and $C x$. tritaeniorhynchus abundance was least. However, $C x$. tritaeniorhynchus abundance increased daring DJF due to less rainfall. Similarly, the abundance of $C x$. gelidus was maximum in December. Two distinct peaks were observed once in May-June and the other in November-December-January. During the high rainfall months JJAS, the abundance was very low.

The abundance of Culex mosquitoes is also influenced by habitat availability. During paddy cultivations in the rainy season (JJAS), reduction of breeding sites may have an impact on the abundance. In Alappuzha district farmers produce two crops a year, with sowing taking place between in November (for winter crop) and an additional season in June (monsoon crop). During the post-harvesting periods (March to May/June and September to October/November) the paddy field areas remained unutilized and the adjoining fields were allowed to have free exchange of water or were flooded on purpose to cause decomposition of weeds along with the paddy stubbles, thus, generating manure. The organic and humic substances thus generated offer rich feed for the $C x$. tritaeniorhynchus larvae. Thus, larval density, as high as $\geq 350$ larvae/dip have been recorded (authors institutional 
survey records, hitherto unpublished). Before sowing the water was drained off and tractor tillage practiced for preparing the soil for next cultivation. But the usage of these tractors creates new mosquito breeding habitats (small pits made by tractor tyre) and probably increasing the mosquito density. Major mosquito species recorded in these areas were freshwater mosquitoes such as $C x$. tritaeniorhynchus and $C x$. gelidus. The abundance of these vector mosquitoes in the presence of suitable virus reservoir host population (pig, birds, etc.) (Khoobdel et al., 2019) increased public health risk for west Nile and Japanese encephalitis viruses in the human settlements along the Arabian Sea shoreline in Alappuzha.

Work done by Sulesco et al. $(2013 ; 2015)$ highlights the importance of mosquito surveys in European regions with rich vegetation, large resident bird population and frequent migratory birds. The presence of large bird population (viral reservoirs), advent of seasonal migratory birds each year together with human migrations due to increased tourism and economic activities, the Alappuzha district coastline remain venerable to vector-borne viral diseases. Considering the sporadic outbreaks of West Nile and Japanese encephalitis in the past and with the bird population being reservoirs for these pathogens, it is important to study the vector population in the Alappuzha district, especially along the coastline. The fact that $C x$. tritaeniorhynchus is eudominant and $C x$. gelidus being the dominant species has potential human health implications in our study area (Bolling et al., 2009; Barker et al., 2010) .

Overall, the 12-months study revealed the demographic diversity of mosquito population in the human settlements along the Arabian Sea shoreline in Alappuzha district, Kerala, India. Key findings included: 1) existence of 20 species in the study area, but all species were not equally abundant (high species richness and moderate evenness as estimated by Shannon indices), 2) higher diversity of Culex species with higher degree of dominance for three Culex species. Also, the mosquito community was composed of a few abundant and a high number of rare species, establishing a clear relationship between Culicidae abundance and environmental parameters. Though $C x$. gelidus and $C x$. tritaeniorhynchus were highly prevalent in the area, West Nile and Japanese Encephalitis viruses were not detected from the field-caught mosquito vectors. The study provided valuable information about the mosquito demographics and seasonal variability of abundance in human settlements along the Arabian Sea shoreline in Alappuzha, India. Knowledge of mosquito demographics and seasonal variability is essential for initiating effective control measures. Considering the vulnerability of the area to vector-borne diseases, it is recommended that further studies should be initiated to determine the association between vector biodiversity and risk of viral disease transmission to humans.

\section{Authors' contributions}

Both authors planned and designed the study. RB carried out the field work and entomology laboratory work. PS contributed in data management and mathematical analyses. RB and PS participated in interpretations of the results and manuscript writing. All authors read and approved the final manuscript.

\section{Acknowledgements}

Authors would like to thank Ms. Arathy Nadh and Ms. Sahina S for their technical help in field work. The authors are also acknowledging Rice Research Station, Mankombu, Alappuzha, for the provision of climate data.

\section{References}

Angle B., and Joshi V., 2008, Distribution and seasonality of vertically transmitted dengue viruses in Aedes mosquitoes in arid and semi-arid areas of Rajasthan, India, J Vector Borne Dis., 45(1):56-59

Balakrishnan A., Thekkekara R., and Tandale B., 2016, Outcomes of West Nile encephalitis patients after1 year of West Nile encephalitis outbreak inKerala, India: A Follow-Up Study, J Medical Virol., 88(11):1856-1861

https://doi.org/10.1002/jmv.24545

PMid:27061922

Balakrishnan A., Thekkekara R., Sapkal G., and Tandale B., 2017, Seroprevalence of Japanese encephalitis virus \& West Nile virus in Alappuzha district, Kerala, Ind J Medical Res, 146(Supp. 1): S70-S76

https://doi.org/10.4103/ijmr.IJMR_1638_15

PMid:29205199 PMCid:PMC5735574 
Balasubramanian R., and Nikhil T.L., 2015, Effects of rainfall and salinity increase on prevalence of vector mosquitoes in coastal areas of Alappuzha district, Kerala, J Environ Biol. 36(6): 1325-1328

Barker C., Eldridge B., and Reisen W., 2010, Seasonal abundance of Culex tarsalisand Culex pipienscomplex mosquitoes (Diptera: Culicidae) in California, J Med Entomol, 47(5):759-768

https://doi.org/10.1093/jmedent/47.5.759

PMid:20939368 PMCid:PMC2965637

Bolling B., Barker C., Moore C., Pape W., and Eisen L., 2009, Seasonal patterns for entomological measures of risk for exposure to Culex vectors and West Nile virus in relation to human disease cases in northeastern Colorado, J Med Entomol, 46(6):1519-1531

https://doi.org/10.1603/033.046.0641

PMid:19960707 PMCid:PMC2802831

Bueno-Mari R., and Jimenez-Peydro R., 2015, First observations of homodynamic populations of Aedes albopictus (Skuse) in Southwest Europe, J Vector Borne Dis., 52(2):175-177

Dash A., Bhatia R., Sunyoto T., and Mourya D., 2013, Emerging and re-emerging arboviral diseases in Southeast Asia, J Vector Borne Dis, 50(2): 77-84

Epstein P., 1998, Global warming and vector-borne disease, Lancet, 351(911): 1737 https://doi.org/10.1016/S0140-6736(05)77777-1

Gould E., and Higgs S., 2009, Impact of climate change and other factors on emerging arbo-virus diseases, Trans. Roy Sco Trop Med Hyg., 103(2):109-121 https://doi.org/10.1016/j.trstmh.2008.07.025 PMid:18799177 PMCid:PMC2915563

Gubler D.J., 2010, The global threat of emergent/reemergent vector borne diseases, In Vector Biology, Ecology and Control, Edited by Arkinson PW.Dordrecht, Springer, Nederlands, 39-62 https://doi.org/10.1007/978-90-481-2458-9 4 PMCid:PMC7120987

Kalaiyarasu S., Mishra N., Khetan R., and Singh V., 2016, Serological evidence of widespread West Nile virus and Japanese encephalitis virus infection in native domestic ducks (Anas platyrhynchosvardomesticus) in Kuttanad region, Kerala, Comparative Immunology, Microbiology and Infectious Diseases, 48: $61-68$ https://doi.org/10.1016/j.cimid.2016.08.002 PMid:27638121

Khoobdel M., Keshavarzi D., Mossa-Kazemi S., and Sobati H., 2019, Species diversity of mosquitoes of the Genus Culex (Diptera, Culicidae) in the coastal areas of the Persian Gulf, AIMS Public Health, 6(2): 99-106

https://doi.org/10.3934/publichealth.2019.2.99 PMid:31297396 PMCid:PMC6606530

Kumawat R., Singh K., Bansal S., and Singh H., 2014, Use of different coloured ovitraps in the surveillance of Aedes mosquitoes in an arid-urban area of western Rajasthan, India, Vector Borne Dis., 51(4): 320-326

Lafferty K., 2009, The ecology of climate change and infectious diseases, Ecology, 90(4): 888-900 https://doi.org/10.1890/08-0079.1 PMid: 19449681

Manimunda S., Sugunan A., Rai S., Vijayachari P., Shriram A., Sharma S., Muruganandam N., Chaitanya I., Guruprasad D., and Sudeep A., 2010, Short report: outbreak of Chikungunya fever, Dakshina Kannada District, South India, 2008, Am. J. Trop. Med. Hyg, 83(4): 751-754 https://doi.org/10.4269/ajtmh.2010.09-0433 PMid:20889860 PMCid:PMC2946737

Monaghan A., Sampson K., Steinhoff D., Ernst K., Ebi K., Jones B., and Hayden M., 2018, The potential impacts of $21^{\text {st }}$ century climatic and population changes on human exposure to the virus- vector mosquito Aedes aegypti, Climatic Change, 146(3-4):487-500 https://doi.org/10.1007/s10584-016-1679-0 PMid:29610543

Mourya D., Shil P., Sapkal G., and Yadav P., 2016, Zika virus: Indian perspectives, The Indian J Medical Res 2016, 143(5): 55 https://doi.org/10.4103/0971-5916.187103 PMid:27487998 PMCid:PMC4989828

Nikookar S., Moosa-Kazemi S., Oshaghi M., Vatandoost H., Yaghoobi-Ershadi M., Enayati A., Motevali-Haghi F., Ziapour S., and Fazeli-Diman M., 2015, Biodiversity of culicid mosquitoes in rural Neka township of Mazandaran province, northern Iran, J Vector Borne Dis, 52(1): 63-77

Rieter P. 2001, Climate change and mosquito-borne disease, Environ Health Persp, 109(Suppl i):141-161 https://doi.org/10.1289/ehp.01109s 1141 PMid:11250812 PMCid:PMC1240549

Roiz D., Ruiz S., Soriguer R., and Figuerola J., 2014, Climatic effects on mosquito abundance in Mediterranean wetlands, Parasites and Vectors, 7(1): 333 https://doi.org/10.1186/1756-3305-7-333 PMid:25030527 PMCid:PMC4223583 
Journal of Mosquito Research 2020, Vol.11, No.2, 1-11

http://emtoscipublisher.com/index.php/jmr

Shil P., Sapkal G., Patil A., Gunjal S., and Sudeep A., 2018a, Meteorological parameters and seasonal variability of mosquito population in Pune Urban Zone, India: ayear-round study, 2017, J Mosquito Res., 8(3): 18-28

https://doi.org/10.5376/jmr.2018.08.0003

Shil P., Kothawale D., and Sudeep A., 2018b, Rainfall and Chikungunya incidences in India during 2010 2014, Virus Disease, 29 (1): 46-53 https://doi.org/10.1007/s13337-018-0428-6 PMid:29607358 PMCid:PMC5877844

Shope R., 1991, Global climate change and infectious diseases, Environ Health Persp, 96:171-174

https://doi.org/10.1289/ehp.9196171

PMid:1820262 PMCid:PMC1568225

Spellerberg I., and Fedor P., 2013,A tribute to Claude Shannon (1916-2001) and a plea for more rigorous use of species richness, species diversity and the 'Shannon-Wiener' Index,Global Ecology and Biogeography, 12(3): 177-179 https://doi.org/10.1046/j.1466-822X.2003.00015.x

Sudeep A., and Parashar D., 2008, Chikungunya: an overview, J Biosciences, 33(4): 443-449 https://doi.org/10.1007/s12038-008-0063-2

PMid: 19208970

Sudeep A., Hundekar S., Jacob PG, Balasubramanian R., Arankalle V., and Mishra A., 2011, Investigation of a Chikungunya-like illness in Tirunelveli district, Tamil Nadu, India 2009-2010, Tropical Medicine and International Health, 16(5): 585-588 https://doi.org/10.1111/j.1365-3156.2011.02743.x PMid:21371218

Sulesco T., Toderas L., and and Toderas I., 2013, A recent survey of the mosquito (Diptera: Culicidae) fauna and seasonal human biting activity in the city of Chisinau, Moldova, J European Mosq Control Assoc., 31: 1-7

Sulesco T., Toderas L., Uspenskaia I., and Toderas I., 2015, Larval habitats diversity and distribution of the mosquito (Diptera: Culicidae) species in the Republic of Moldova, J Med entomology, 52(6): 1299-1308 https://doi.org/10.1093/jme/tjv142

PMid:26364191 